самостоятельность среднего содержания в надземных органах растительности степей и нор степных млекопитающих свидетельствует о наличии регуляторных механизмов видов растений, произрастающих в пределах роющей активности зверька, эволюция которых происходила совместно.

$$
* * *
$$

1. $\quad$ Горный массив Монгун-Тайга / ред. К.В. Чистяков. - СПб: Арт-Экспресс, 2012. - 310 с.

2. Курбатская С.С., А.М. Самдан, Т.Н. Прудникова, С.К. Кужугет, А.М. Монгуш, У.-М.Г. Чаш, О.О. Момбулай, Ш.Д. Ховалыг. Ландшафтно-географические исследования южного макросклона Восточного Танну-Ола (Тува) // Состояние и освоение природных ресурсов Тувы и сопредельных регионов Центральной Азии. Эколого-экологические проблемы природопользования / Отв. редактор докт. геол.-мин. Наук В.И. Лебедев. Кызыл: ТувИКОПР СО РАН, 2014. Вып. 13. - С. 121-138.

3. Ондар С.О. Экологические перестройки в эволюции экосистемного уровня. - Кызыл: РИО ТувГУ, 2015. $-318 \mathrm{c}$.

\title{
Мустафаева С.Э.к. \\ Исследование состава мочи в норме и на фоне гиповолемического шока
}

Бакинский Государственный Университет (Азербайджан, Баку)

doi: 10.18411/sr-10-04-2021-15

Научный руководитель

Мамедова Н.Т.к.

Аннотация
Гиповолемический шок - это неотложное, стремительно развивающееся и
несущее прямую угрозу жизни состояние, и относится к числу так
называемых сердечнососудистых катастроф. Подобного рода статусы характеризуются
рядом общих клинических и патофизиологических особенностей; малопредсказуемой
динамикой в ответ на терапевтическое вмешательство; высокой летальностью, если
помощь оказывается своевременно и грамотно.
Ключевые слова: гиповолемический шок, пиелонефрит, протеинурия,
кетоновые тела, билирубин, сахарный диабет

Гиповолемический шок характеризуется нарушениями гемодинамики, микроциркуляции, тканевой перфузии, сопровождающиеся гипоксией, и нарушениями клеточного метаболизма. В результате внутриклеточного дефицита кислорода нарушаются процессы энергообеспечения тканей вследствие резкого снижения ресингеза АТФ. Недостаток макроэргов, в свою очередь, вызывает угнетение специфических функций клеток и пластических процессов в них, т.е. нарушаются работа АТФаз, ионный гомеостаз (перегрузка клетки Са2+), структурная организация мембран из-за их дефосфорилирования, активации фосфолипаз; синтез и ресинтез мембранных фосфолипидов; происходит деградация адениловых нуклеотидов, прекращается ß-окисление свободных жирных кислот, усиливаются процессы ПОЛ (1).

Таким образом, состояние шока представляет собой циркуляторный и метаболический ответ организма на агрессию среды, который филогенетически закодирован в нейроэцдокринной системе. Истощение её функциональной активности приводит к нарушению нейрогормональной регуляции жизнеобеспечивающих функций.

Исходя из этого, противошоковая терапия должна быть направлена на коррекцию в первую очередь центральных механизмов регуляции, ответственных за способность организма противостоять возникшим нарушениям. 
Методы исследования. Лабораторные исследования являются дополнительным методом, одной из важнейших частей обследования пациента. В ряде случаев их данные оказывают решающее значение при постановке диагноза. Исследование мочи позволяют определить физические свойства, химический состав, микроскопию осадка мочи и указывают на состояние почек и их функцию, а так же позволяют судить о наличии поражения ряда других органов и систем. Поэтому они являются составной частью в общем обследовании пациента.

Исследовали физико-химические показатели состава мочи в норме и при гиповолемическом шоке (2): прозрачность мочи определялась в цилиндре в проходящем свете. Причину помутнения определяли при помощи микроскопии. Реакция мочи $(\mathrm{pH})$ определялось с помощью индикаторов лакмуса: синяя лакмусовая бумага в кислой среде краснеет, красная лакмусовая бумажка в щелочной среде синеет.

Принцип метода качественного определения белка в моче основан на том, что белок под действием неорганических кислот коагулирует (становится видимым). Степень помутнения мочи зависит от количества белка, обнаружение которого проводилось при помощи $20 \%$ сульфосалициловой кислоты. Качественное определение белка в моче проводили тест - полосками. Для выявления протеинурии используют различные монотест - полоски: Альбуфан, Альбустикс, Биофан Е и политесты: Трискан, Нонафан и др. Количественное определение обнаружения белка в моче проводилось по методу Робертса - Стольникова.

Качественное определение сахара в моче проводили реактивом Гайнеса, количественное колориметрическое определение сахара в моче производили по шкале Альтгаузена после положительной качественной реакции.

При обнаружении сахара в моче исследовали кетоновые тела экспресс - тестами (кетофан) или пробой с нитропруссидом натрия.

Определение желчных пигментов в моче проводилось по методу Труссо Розина.

Для исследования мочи приготовленный нативный препарат помещали на столик микроскопа и микроскопировали сначала при малом (7x8), а затем под среднем (7x40) увеличении, просматривая весь препарат.

Результаты исследования. В таблице приведены показатели общего анализа мочи у взрослых внорме и при наличии отклонений.

$\begin{array}{lll}\text { Обозначение } & \text { Название показателя } & \text { Норма с указанием единицы измерения } \\ \text { COLOR } & \text { цвет } & \text { соломенный } \\ \text { pH } & \text { кислотность } & 5-7 \\ \text { PRO } & \text { белок } & \text { нет или } 0,033 \text { г/л } \\ \text { GLU } & \text { глюкоза } & \text { нет или до } 1 \text { ммоль/л } \\ \text { BIL } & \text { билирубин } & \text { нет или до } 8,5 \text { мкмоль/л } \\ \text { URO } & \text { уробилиноген } & \text { нет или до } 35 \text { мкмоль/л } \\ \text { KET } & \text { кетоновые тела } & \text { нет или до } 0,5 \text { ммоль/л } \\ \text { BLD } & \text { эритроциты } & \text { до } 2 \text { в п/3 } \\ \text { LEU } & \text { лейкоциты } & \text { до } 5 \text { в п/3 }\end{array}$

Гиповолемический шок обусловлен критическим уменьшением внутрисосудистого объема. Уменьшение венозного возврата приводит к снижению наполнения желудочков и ударного объема. Если не компенсировать увеличение частоты сердечных сокращений, сердечный выброс уменьшается. Распространенной причиной может быть кровотечение (геморрагический шок), как правило, из-за травмы, хирургического вмешательства, язвенной болезни, варикозного расширения вен пищевода или разрыва аневризмы аорты. Кровотечение может быть явным (например, кровавая рвота, мелена) или скрытым (например, разрыв при внематочной 
беременности). Гиповолемический шок также может возникнуть в результате увеличения потерь жидкости организмом, кроме потери крови.

Гиповолемический шок, вызванный потерей жидкости в организме

\begin{tabular}{|c|c|}
\hline Участок, теряющий воду & Механизм потери \\
\hline Кожа & $\begin{array}{l}\text { Тепловой или химический ожог, потливость из-за чрезмерного } \\
\text { воздействия тепла }\end{array}$ \\
\hline Желудочно-кишечный тракт & Рвота, диарея \\
\hline Почки & $\begin{array}{c}\text { Сахарный диабет или несахарный, недостаточность } \\
\text { надпочечников, (потеря солей) нефрит, полиурическая фаза } \\
\text { после острого повреждения систему трубочек, использование } \\
\text { сильнодействующих диуретиков }\end{array}$ \\
\hline $\begin{array}{c}\text { Внутрисосудистая } \\
\text { жидкость/внесосудистое } \\
\text { пространство }\end{array}$ & $\begin{array}{c}\text { Повышение проницаемости капилляров вторичное по } \\
\text { отношению к воспалению или травматическому повреждению } \\
\text { (например, раздавливание), гипоксии, остановке сердца, сепсису, } \\
\text { ишемии кишечника, острому панкреатиту }\end{array}$ \\
\hline
\end{tabular}

Гиповолемический шок может быть связан с недостаточным потреблением жидкости .Недостаточное количество воды, неврологические нарушения ослабляют чувство жажды, физиологические расстройства могут уменьшить ее потребление.У госпитализированных пациентов гиповолемия может усугубляться, если ранние признаки недостаточности кровообращения неправильно расценивались как сердечная недостаточность, в результате задержки жидкости при использовании диуретиков $(3,4)$.

В норме свежевыпущенная моча прозрачна. Различные оттенки мочи при гиповолемическом шоке указывают на наличие следующих патологий: «мясных помоев» - острый гломерулонефрит, бурая и тёмная - при гемолитической анемии, чёрная - при пароксизмальной ночной гемоглобинурии и т.д. Мутность обусловлена попаданием в урину форменных элементов крови, бактерий, клеток эпителия, жировых частиц, солей.

В норме при смешанном питании реакция мочи слабокислая или нейтральная

( $\mathrm{pH} 4,5$ - 7,4). При гиповолемическом шоке происходит снижение $\mathrm{pH}$ мочи (pH около 5 и ниже) - закисление мочи.

Белок в норме в моче содержится в минимальных количествах, которые не обнаруживаются обычными качественными реакциями. Его наличие в моче называется протеинурией. Верхняя граница нормы белка в моче - 0,033 г/л. Если содержание белка выше этого значения, то качественные пробы на белок становятся положительными. При наличии белка, моча в пробирке мутнеет. Обнаружение большого количества белка в моче происходит при гломерулонефрите, диабетическом поражении почек, нарушении кровообращения в почке при сердечной недостаточности.

В моче здорового человека сахар отсутствует. При наличии сахара в моче образуется окрашивание (от желтого до бурого). Окраску раствора сравнивают с цветом стандартной шкалы. На фоне гиповолемического шока при расшифровке анализа мочи людей с подозрением на сахарный диабет показатель глюкозы крайне важен. В совокупности с анализом крови он даёт информацию о наличии и прогрессировании этого заболевания.

В норме показатель на билирубин должен быть отрицательным. Билирубинурия указывает на поражение печени и затруднение желчеоттока при гиповолемическом шоке.

При выявлении сахара в моче проводят обязательное исследование на кетоновые тела. В норме кетоновых тел не обнаруживают - реакция отрицательная. Их проникновение в мочу при гиповолемическом шоке показывает декомпенсацию сахарного диабета и высокий риск развития гипергликемической комы. 

фрагменты:

При микроскопическом анализе осадков мочи просматриваются следующие

Эпителий постоянный компонент мочи. При микроскопии обнаруживают элементы плоскоклеточного, переходного, почечного эпителия. По ним придерживаются следующих количественных ориентиров:

- $\quad$ плоский - до 3-5 клеток в п/3;

- $\quad$ переходный - не более 1 клетки в п/3;

- $\quad$ почечный - должен отсутствовать.

При гиповолемическом шоке происходит повышение или появление эпителиальных клеток в осадке при гломерулонефрите, пиелонефрите и т.д.

Патологическое повышение эритроцитов (>2 в п/3) при гиповолемическом шоке связано например, геморрагическим диатезом, гломерулонефритом, пиелонефритом, травмой почки и т.д.

Лейкоцитурия (> 5 в п/3) наблюдается также при гиповолемическом шоке ( при пиелонефрите, гломерулонефрите и т.д.). Чрезмерное накопление лейкоцитов вызывает помутнение мочи, называемое пиурией.

Физиологическая моча не содержат цилиндры. Их образование происходит при поражениях почек. На фоне гиповолемического шока при анализе мочи можно встретить следующие виды цилиндров:

- $\quad$ гиалиновые - присутствуют при пиелонефрите, гломерулонефрите;

- $\quad$ зернистые - обусловлены пиелонефритом, гломерулонефритом и т.д.;

- $\quad$ восковидные - при нефротическом синдроме, и т.д.

Также встречаются лейкоцитарная, эритроцитарная и эпителиальная форма цилиндров. Они указывают на первичную или вторичную патологию почек.

Бактерии, грибы и паразиты в норме отсутствуют в моче, их обнаружение связывается с соответствующим заболеванием мочевыводящего тракта.

\section{$* * *$}

1. Егоров И.В., Киселёва А.В., Михайлова Н.Н., Уланова Е.В., Фоменко Д.В. Влияние мелатонина на энергообеспеченность тканей в динамике экспериментального травматического шока // Фундаментальные аспекты медицины катастроф Сибири (Сб. тезисов докладов региональной научно-пракг. конф.)-Новосибирск. - 1998. - С.87-89.

2. Мурадеева Г.В., Письменная С.В., Серова С.С. Основы лабораторной диагностики: Учебнометодическое пособие. - Архангельск: ГОУ СПО «АМК», 2008. -С.62-77, 140-159.

3. Holcomb JB, Tilley BC, Baraniuk S, et al: Transfusion of plasma, platelets, and red blood cells in a 1:1:1 vs a 1:1:2 ratio and mortality in patients with severe trauma: the PROPPR randomized clinical trial. JAMA 313(5):471-482, 2015. doi:10.1001/jama.2015.12

4. Cannon JW, Khan MA, Raja AS, et al: Damage control resuscitation in patients with severe traumatic hemorrhage: A practice management guideline from the Eastern Association for the Surgery of Trauma. J Trauma Acute Care Surg 82(3):605-617, 2017. doi: 10.1097/TA.0000000000001333.

\section{Содаткадамова T.M. \\ Эколого-биологические особенности местных и интродуцированных сортов абрикоса в условиях высокогорья Памира}

Хорогский государственный университет им.М.Назаршоева

(Таджикистан, Хорог)

doi: $10.18411 / s r-10-04-2021-16$

\section{Аннотация}

Дана эколого-биологическая характеристика некоторых интродуцированных и местных сортов и форм абрикоса в условиях высокогорья Памира. Выявлено, что в условиях высокогорья Памира произрастает только один вид абрикоса-абрикос обыкновенный (Armeniaca vulgaris lam.).

Ключевые слова: абрикос, высокогорья, интродукция, местные,формы 